\title{
The Perception of Students towards the Community Colleges' \\ Courses That Offered in Malaysia
}

\author{
Dr. Ahmad Esa \\ Faculty of Technical Education \\ Universiti Tun Hussein Onn Malaysia \\ Tel: 60-19-7677349Ｅ-mail: ahmad@uthm.edu.my
}

Abdul Rasid Abdul Razzaq

Faculty of Technical Education

Universiti Tun Hussein Onn Malaysia

Tel: 60-19-7723536_E-mail: rasid@uthm.edu.my

\author{
Alias Masek \\ Faculty of Technical Education \\ Universiti Tun Hussein Onn Malaysia
}

Tel: 60-7-4538206 E-mail: aliasmasek@gmail.com

\author{
Dr. Asri Selamat \\ Faculty of Technical Education \\ Universiti Tun Hussein Onn Malaysia \\ Tel: 60-13-7272780Ｅ-mail: asri@uthm.edu.my
}

\begin{abstract}
Government has allocated funds to build and upgrade the present infrastructures to deal with the increasing capacity of students at community colleges. Among its reasons were the needs to strengthen the training and skills enhancement system and to encourage participation from SPM leavers. However, in fact not many of them interested to enroll and fill up the available quota. Therefore, this study was conducted to get views on SPM leaver's perception towards community colleges and the courses offered. The quantitative survey designed which used questionnaires as an instrument. Samples of 105 respondents who were attending the National Service Training Program (NSTP) at Semberong Camp were chosen to represent the whole population of SPM leavers for the year of 2007. Findings showed that the perceptions of SPM leavers towards community colleges were at a moderate level, such as their acceptance towards the courses offered. At the same time, they were alert and informative pertaining to community colleges and the courses being offered. Others aspects have also taken into account such as participations, triggers, interest in courses and demographic factors. In summary, SPM leavers' perception and acceptance towards community colleges and the courses offered were at a moderate level and it illustrated tendencies towards positive perception.
\end{abstract}

Keywords: Perceptions, Technical courses, Technical and Vocational education, Community college

\section{Introduction}

Malaysia is now a developing country towards vision 2020. Within this context, the government has worked out to put on effort in looking into infrastructures development and economic revitalization. The essential steps to work on infrastructures before moving to the next steps which is more focusing on economic revitalization that based on 
knowledge (Malaysia Ministry of Finance, 2008) was seen as good in potential. The first emphasized element is to intensify training and up skilling workers to develop the valuable human capital.

About of RM 2 billion had been allocated for training and up skilling the workers program (Malaysia Ministry of Finance, 2008). The amount was distributed accordingly to particular firm such as Pusat Giat MARA (PGM), Industrial Training Institutes (ILP) and National Youth Training Institutes (IKBN) (Malaysia Ministry of Finance, 2008). The allocated funds were also used to increase the numbers of Public Skills Training Institutes (ILKA) which is core business in focusing skills enhancement, technical and vocational training such as community colleges (Malaysia Ministry of Finance, 2008).

Community college is a place to get a valuable knowledge (technical and vocational knowledge and skills) that requires by the community and employers (Emeagwali, 2007). Technical and vocational knowledge which form the basic skills in undertaking task is the case in point (Jacobs and Grubb, 2003; UNESCO-UNEVOC International Center for Technical and Vocational Education and Training, 2006; Oketch, 2007). Inline with the opinion, Jacobs and Grubb (2003) have expended broader definition where the community college plays dominant roles in producing workers. Thus from this view, we could understand that ready workers constitute skilled workers, while the community college is the place for producing those particular skilled workers. Hence, in response to the current industrial demands, the government rationale behind the invention over community college was seen crucial.

Community college is a technical college under Ministry of Higher Education (MOHE) which dedicated to provide platform and opportunity for societies to improve their technical and vocational skills. As cited from Jabatan Pengajian Politeknik Dan Kolej komuniti (JPPKK) (2006) web portal, the main purpose of the community college is to provide a dynamic and quality education and training at all levels of societies for workplace. In particular, community college is to provide second chances for those SPM leavers to further study and also to get them ready before they involve into workplace (JPPPK, 2006). The community college invention objectives aimed for more details are as follows:

(i) To host and provide alternative pathway to secondary school SPM leavers

(ii) To host and provide lifelong learning knowledge to the community (learning communities).

(iii) To provide training and up skilling and re-skilling for the local labor need.

(iv) To provide strategic networking for social strengthening activities.

For the year 2006, 34 community colleges were currently in operation and have successfully produced a number of 4061 graduates in various fields (Malaysia Ministry of Higher Education, 2007). It is the government hopes that the number of skill workers would increase inline with the number of community college will rise to one community college for each Parliament. At the same time, the several choices of courses offered could manage to attract youngster to enroll in the institution.

The unique of community college is the curriculum design which is developed from the collaboration between Malaysia Ministry of Higher Education and industrial bodies. The number of 33 private companies including Telekom Malaysia Bhd, MIMOS Bhd, DRB-Hicom Bhd and etc have being in consensus (MOU) to ensure the industrial related curriculum (JPPKK, 2006). As such, this is considered as the best strategy to provide marketable graduate of the community college.

Sijil Pelajaran Malaysia (SPM) examination is a national examination which is important to assess academic competencies for fifth form of secondary school student in Malaysia. The main purpose is to stratify and assist to determine the students' academic pathway towards further education at tertiary level (Wikipedia, 2008). According to Wikipedia, SPM examination is equivalent to British General Certificate of Secondary Education (GCSE) and is taken by those who ages 17 years old. However, for those who attended pre-secondary school would take the SPM examination at the age of 18 .

The SPM leavers are students who have sat the SPM examination at particular year of examination. In the report of Bernama (2007), there are 439255 candidates who have sat for the examination for the year 2007. If we seek to review on the pass several years as in 2006, the amount of 416717 candidates had sit for the exam and 437896 for the year 2005. However, the number of candidates increase and likely to rise in the forthcoming years inline with the increasing of Malaysian occupation statistic projection towards year 2020.

\section{Background of problem}

Cited from Oketch (2007), Technical and Vocational Education field is closing related to workplace and training. Inline with the government mission, youths and youngsters role should not be neglected within this field. Though, as provision for producing skilled workers, they were expected to fill up the jobs market especially in service field that will be invented along with our country's development pace toward advance (Jacobs and Voorhees, 2006). In addition, as statistic projection by Western, illustrating that most of the future jobs opportunity emerge would be in the service sectors (Jacobs and Voorhees, 2006). Therefore, technical and vocational field should emphasize in producing 
manpower in services sectors and other sectors too including automotive, manufacturing, construction, business, and engineering and information technology.

If we look into current scenario of manpower usage, these sectors were not filled up by the local youths and youngsters. As consequences, almost 2 million immigrants work in various sectors including manufacturing, construction, agriculture and household maid instead (Mohd. Yusof, Rajudin and Buntat, 2007). The circumstances depicting that our country has shortage in manpower to replace them. Is this circumstance the consequences of the overlooked by the government to emphasis on this sector from the beginning? If negative, why these jobs opportunity not filled up by the local youngsters? Are these local youngsters doing not have the skills in the particular area? Or probably not interested? And the most important question is, are the immigrants all skilled workers?

In 2006, 37 community colleges had been in operation and capable to train 23300 students at a time (Utusan Malaysia, 12 November 2007). These big number provides opportunities and chances for those and it is believed to be increased every year inline with the increasing number of community colleges as in plan. However, according to the enrolment report on community colleges, it is apparently low especially from those SPM leavers and local community. At this point, the question raise is about why they seem not interested to enroll in the community colleges especially for those failures to get place in the university?

\section{Statement of problem}

Government intended to encourage the young and youth participations in skills training program. For this to occur, yearly national investment budget had allocated big amount of money purposely for that means. The funds were used to build and upgrade the present infrastructures to increase the capacity of students particularly for community colleges. As a result, it can now providing SPM leavers with wider opportunities and alternatives especially for those who are weak in academic streams and failure to get place in university. Although, the SPM leavers increase each year, in fact not many of them interested to enroll and fill up the available quota. Therefore, this study was conducted to review the perception of SPM leavers towards community colleges' and the courses offered which portraying their expectation towards courses being offered and the community colleges itself.

\section{Research questions}

The research highlighted the outline area of:

a) What is SPM leaver's perception towards community college and courses offered?

b) What is the SPM leaver's information level towards community college and courses offered?

c) What are the promotion methods that assist student to get informed pertaining to community college and courses offered?

d)

Are the lists of courses offered fulfilled SPM leavers' interest?

e) What are the attributes considered which influence their decision to join community college?

f) Is there a significant different between perception and socio demographic factors with:

i) Gender

ii) SPM result

iii) Race

\section{Perceptions}

Perception defines as perceives or views, it also synonym with word acceptance (Liu and Gentle, 2005; Smart and Cappel, 2006; Maniam and Liong, 2007) or could be best described with depicting or portraying or thinking about something (Dewan Bahasa Dan Pustaka, 2005). Therefore, it is important to get views on SPM leavers' perception towards community colleges. Furthermore, perception shows an evaluation made by persons (Choi, Kim and Lee, 2000). Thus, how could they join community colleges if priorly they have made negative evaluation on them? In addition, the information level is believed could influence their perception regarding on certain things (Abd Ghafar, 2003).

Several previous researches demonstrated a different findings pertaining to this matter. As the case in Brunei, the researcher has found that the local citizen barely accepting the industrial and private sectors in Technical and Vocational Education (Minnis, 2000). The circumstance likewise occurs in Africa, most African has concerned bad image and low status on vocational courses (UNESCO-UNEVOC International Center for Technical and Vocational Education and Training, 2006). This exhibits with gender stereotype that occurs within this field wherein, information technology and electrical engineering were dominated by males (Stanwick, 2006). In addition, they also have found different perception between males and females towards Technical and Vocational Education in Poland (Lobodzinska, 2000).

Some researches have met valuable findings regarding perception towards vocational courses offered especially in community colleges. From this information, it revealed certain hidden keys and formed a turning point towards 
improving Technical and Vocational Education field image and status. This information becomes a valuable input for the aimed cohort to entice those joining community colleges. The authorities could drill down the root of the problem to solve it besides taking the others country experiences as valuable lesson.

\section{Methodology}

The study applied quantitatives research design uses survey questionnaires. The random sample among PLKN Semberong Camp constitutes 105 respondents to represent the whole population of SPM leavers for 2007. According to Bernama (2007), SPM leavers' population for that particular year was 439255 nationwide. The descriptives analysis involves mean and percent for research question 1 to 5 . While for inferential statistic was using independent t-test. For the Likert Scale questions, the mean score determination were according to the range listed as in Table 1 (Kiong, Arof, Omar and Yan, 2005)

\section{Insert Table 1 here}

The questionnaire was developed referring to the survey questionnaire by Liu and Gentle (2005). The items were modified and adapted to drive toward objectives and research questions and also to meet the respondent level. Subsequently questionnaire was tested for reliability and validity. Repeated pilot test were run to ensure the wording and statements given firms in meaning and to decrease the possibility of confusing. Furthermore, it also to ensure the combination of items could delineate the desired output as stated in objectives (Johnson and Christensen, 2000; Wiersma, 2000). The pilot test was run on different group of fifth and sixth form student at the nearest secondary school. The first test was involved 8 samples of sixth form student, thus some rectifications were made, and 10 samples of fifth form student for the second test and the third test took 14 samples among fifth and sixth form student. The reliability analysis Alpha Cronbach is 0.89 . The pilot test was repeated as that pace is to see the effect on the first modification on the previous test. According to Johnson and Christensen (2000), it is adequate to take 5 to 10 sample as respondent to test the questionnaire instrument developed. In addition, a set of questionnaire were checked and verified by three experience lecturers.

\section{Findings and discussions}

The majority of the participants involved in the study were females, constituting $53.3 \%$ of the data sample that represent of 56 females of 105 respondents. Among them, 56 respondents were Malay, 41 were Chinese, 7 Indian and 1 for other. 75 among respondents were reported pass in the SPM examination while another 30 respondents were failed or do not sit the examination (those absent from school).

The first and the second relevant survey questions were "What is SPM leavers' perception towards community college and courses offered?" and "What is the SPM leavers' information level towards community college and courses offered?" Respondents have to response on 8 items pertinent to their perception and information level. Findings showed that moderate level of SPM leavers' perception towards community colleges with mean 3.66 and the perception towards courses offered likely at the same extent with 3.63 in mean. While the information level of SPM leavers' towards community colleges and courses offered at moderate level with 3.59 and 3.45 respectively. The findings tabulated as in Table 2.

\section{Insert Table 2 here}

Respondents agreed within a set of items where the community colleges provide them opportunities to built and develop their future carrier. The findings firmed by Barabasch (2006) that in his qualitative research has found that participant perceive that the skills training in community colleges could help them to grasp the quality jobs for their future. This study finding showed likewise and more it provided the opportunity to further study to the high levels. The other researchers also agreed with the research findings such as Bailey, et al., 2003; Liu and Gentle, 2005; Bailey, et al., 2007.

Within these research findings, respondents' perception towards Technical and Vocational Education were found positive (Daniel and Mukhari, 2001). In some research findings however, community perceived bad image on vocational education as demonstrated in Mustapha, Mohd. Basin and Mohd. Ali. (2003). Indeed, Velde and Cooper (2000) have also firmed that the teachers were concerned that vocational education had a low status in the school and at the same time supporting the UNESCO-UNEVOC International Center for Technical and Vocational Education and Training (2006) views on some of African society.

The third relevant survey question was "What are the promotion methods that assist student to get informed pertaining to community college and courses offered?" The finding showed that the main source as information references were schools and friends with respectively $71.4 \%$ and $70.5 \%$. Interestingly, the speech session programs in the camp represent other sources in the questionnaire information sources list exhibit $9.5 \%$ of the overall respondents. While for the other sources were shown as in Table 3.

As remarked in Liu and Gentle (2005) research findings, teachers were the main source of information reference for student to make decision to join in Technical and Vocational Education. As such, school acts as the main source of 
information references to get know regarding community colleges and other opportunity for furthering study. In relation, friends demonstrated as a second information source for them that commonly the only place to share their stories, sharing ideas, information, and have a chit chats and so on in youth's social life (Mesir, et al., 2006). However, this research finding was against with Liu and Gentle (2005) where friends were not become the main source of information instead.

\section{Insert Table 3 here}

According to the forth relevant question, "Are the lists of courses offered fulfilled SPM leavers' interest?" Two of the listed courses which frequently chosen by respondent which were Hotel Management and Catering and Tourism and Exploration. Mean score according to the interest for the rest are shown as in Table 4.

\section{Insert Table 4 here}

The result seems against for the several previous researches finding where students at Diploma level in Technical and Vocational Education more interested in Business Administration (Stanwick, 2006). Nevertheless, the most popular courses here have found insipid respond from them (Stanwick, 2006). This ambivalence might clarify within the contact of the diversity of social status and the different in thinking maturity of both groups of respondents.

Within these, we have found that the ICT based courses (Such as Computer system and support) became favourite course to respondents which all mean exhibited above 3.0. Most probably the respondent could see the global trend of developing ICT industry which they seeing as an opportunity for future employment. However, the cooling system and air-conditioning courses appeared as the lowest unfavourable course.

The fifth relevant survey question was "What are the attributes considered which influence their decision to join community colleges?" These report findings showed that SPM leavers' considering skills and the chosen courses with score mean 3.74. The value apparently at high level depicting that student concern on the skills offered before making decision to join community colleges. In relation, they also were considering their confident level on the courses that might help them to seek for a job in the future time with score means 3.70. In contrary, the lowest score mean exhibited by the statement "There are no other activities that I could do and it's only to fill in my leisure time". Whilst the other factors listed in the questionnaires were at moderate level.

\section{Insert Table 5 here}

For the sixth question, genders, SPM results and races were taken as comparison point on SPM leavers' perception. The independent t-test result showed that there were significant difference in perception between males and females towards community colleges $(\mathrm{p}=0.008)$. However in contrast, there were no significant difference in perception towards the courses offered $(\mathrm{p}=.989)$. For SPM result, there were no significant difference between those who pass the examination between who failures or do not have SPM (those absent from school) in perception towards courses offered ( $\mathrm{p}=.993)$, while there were difference perception towards community colleges $(\mathrm{p}=0.03)$. At other times, there were no significant difference between Malay and Non-Malay in perception towards courses offered $(\mathrm{p}=0.051)$ and however, there were significant difference in perception between Malay and Non-Malay towards community colleges $(\mathrm{p}=.000)$ in contrast. The data were simplified as in Table 6 .

Perceptions were not influenced by gender within this context (Barry and James, 2000; Daniel and Mukhari, 2001). Nevertheless, in the report of community colleges enrollment for the year 2006 showed the different between the number of males and females (Malaysia Ministry of Higher Education, 2007). The discrepancies evidently showed the contradict perception among these genders. It seems identical findings that strongly supported this study report as in Lobodzinska (2000).

Difference in perception illustrated between those who pass and failed or do not sit the examination (those absent from school) towards courses offered. The simple interpretation from this information is for those who were failed or do not sit the examination (those absent from school) have also probably interested in skills courses compared to academic stream instead. The opportunity should also open to them to enroll in any of certificate courses according to their interest. Particularly, the minimum entry requirements to community colleges should exclude pass in Bahasa Melayu (JPPKK, 2006). If not, this consequently will hinder them to build up themselves as in skilled workers or the valuable human capital cohort for the country's development.

\section{Insert Table 6 here}

As a result, we exhibit significance different in perceptions for the students who were failed or do not sit the examination (those absent from school) towards community colleges. They probably felt that institutions close doors for them. Eventually, they choose to join factory or start own business without skills. However, they still have another choices to get skilled with joining short courses in community colleges to allow them start any business activities with some certain experiences and skills. The basic entry requirement will allow them to do so and it is open to Malaysian citizen. 
Western has evident completely different scenario wherein, most of the high school students would directly entering the jobs market especially for those who have the high credit in occupations (Levesque et al., 2008). Only a few of them choose to join post secondary education (Levesque et al., 2008) even there were certain policies that allow them to participate in dual enrolment school system (Karp, et al. (2007).

From the race point of views, the study finding showed that race was not one of the influencing factors in perception in Technical and Vocational Education courses. As remarked by Barry and James (2000), it was found the similarity within this context but however, perception towards community colleges were found contradict. If we look into the current scenario, we evidently saw that most of the community colleges' students are Malay and only a few of them Non-Malay, particularly Chinese and Indian. This statement supported by Karp, et al. (2007) where they have found enrollment difference among different races into technical courses.

\section{Conclusions and suggestions}

SPM leavers' within this context area of research showed positive perception towards 21 courses offered in community colleges where, their information level at moderate. However, only two of the listed courses were being frequently chosen which were Hotel management \& Catering and Tourism \& Exploration. At the same times, the SPM leavers' have also inclined to show positive perception towards community colleges likewise the information level at moderate too. For both these characteristics, we understood that the information pertaining to community colleges might not be delivered precisely. They were not provided with direct sufficient information on the unique of community colleges from officers in promotion programs. Schools illustrated the main references however, teachers and councilors sometimes might not really sure about it. The stacking information of delivery system seems dearth to deliver precise information by the community colleges' officers groups in the road tour promotion programs.

SPM leavers' considered on several aspects before the decision to join community colleges were made. They concerned about the skills and the courses offered to ensures them could breach into the job markets while completes. They thought the courses should embed with appropriate skills to enable them perform duties and tasks. In addition, the courses offered should also able to convince them and related to the current market demands.

Within these research findings, males indicated inclination to positive perception towards community colleges compared to their counterparts, however, perceptions towards courses offered seems equal. In relations, enrollment data demonstrated exceeding number of males than females in community colleges. Probably, the reasons behind it where the technical courses offered have been long time offered in the others institutions compared to the new born community colleges. At the same times, Malay and Non-Malay have gotten different perception towards community colleges and against for the courses offered. Whilst for SPM result point of views, those who pass or failed or do not sit the examination (those absent from school) have evidently identical in perception towards courses offered. However, they indicated different perception towards community colleges

Further research needs to be undertaken as outlined in this report. In which is as continuing research practices, it will more precise and valuable findings if the respondent aimed for those students who did apply to enroll in but failure to do so. Valuable outcomes could yield in terms of their perception and their pathway for continuing educations. The findings will answer several questions pertaining to acceptance towards community colleges and courses offered.

It is recommended that the case study to be conducted for community colleges which the enrollment rate indicates low. Taking the local vicinity respondents, it will clarify in details on the perception towards community colleges and courses offered. Many interesting findings could reveal important key points including the suitability of the courses offered, the community awareness on Technical and Vocational Education, gender discrimination, races and any other demographics diversity and acceptance towards the availability of community colleges in their vicinity.

\section{References}

Abd. Ghafar, M. N. (2003). Rekabentuk Tinjauan Soal Selidik Pendidikan. Universiti Teknologi Malaysia: Penerbit UTM. 3

Bailey, T., Badway, N. and Gumport, P.J. (2003). For-Profit Higher Education and Community Colleges. Community College Research Center, 16, 1526-2049.

Bailey, T., Jenkins, D. and Leinbach, T. (2007). The Effect of Student Goals on Community College Performance Measures. Community College Research Center, 33, 1526-2049.

Barabasch, A. (2006). No Worries about the Future: Young Adults' Perceptions of Risk and Opportunity While Attending Technical College. Jurnal of Industrial Teacher Education, 43, 20-44.

Barry, C. and James, F. (2000). Factors Influencing A Student's Perception Of The Programs And Services Offered By A Career And Technical Education Student Organization. Annual Conference of Association for Career and Technical Education/International Vocational Education and Training Association. Reports Research 143. Meeting Papers 150. Unpublished. 
Bernama. (2007). 439255 candidates for SPM 2007. [Online] Avaliable: www.bernama.com/bernama/v5/newsindex.php?id=320139 (November 10, 2007).

Choi, Y. S., Kim, J. S. and Lee, B. W. (2000). Public's Perception and Judgment on Nuclear Power. Annals of Nuclear Energy, 27, 295-309.

Daniel, E.A. and Mukhari, A. W. (2001). Technical and Vocational Education: It's Importance as Perceived by Graduates of Secondary Schools in St Lucia. Skudai: Universiti Teknologi Malaysia.

Dewan Bahasa Dan Pustaka. (2005). Kamus Dewan Bahasa Dan Pustaka Kuala Lumpur - Bahasa Melayu Ke Bahasa Melayu. Kuala Lumpur: Dewan Bahasa Dan Pustaka.

Emeagwali, N.S. (2007). Community College Offer Baby Boomers and Encore. [Online] Available: http://www. www.acteonline.org (March 17, 2007).

Jabatan Pengajian Politeknik dan Kolej Komuniti (JPPKK). (2006). Bahagian Pengurusan Kolej Komuniti. [Online] Available: http://jppkk.mohe.gov.my/index.php?option=com_content\&task=view\&id=62 (December 5, 2007).

Jacobs, J. and Grubb, W.N. (2002). Implementing the Education Consensus: The Federal Role in Supporting Vocational-Technical Education. California: Community College Research Center, University of California at Berkeley. Unpublished.

Jacobs, J. and Voorhees, R.A. (2006). The Community College as a Nexus for Workforce Transitions: A Critical Essay. Journal of Applied Researcher in the Community College, 13, 2.

Johnson, B. and Christensen, L. (2000). Educational Research: Quantitative and Qualitative Approaches. Boston : Allyn and Bacon. 51.

Karp, M.M., Calcagno, J.C., Hughes, K.L., Jeong, D.W. and Bailey, T.R. (2007). The Postsecondary Achievement of Participants in Dual Enrollment: An Analysis of Student Outcomes in Two States. National Research Center For Career and Technical Education 2007. Unpublished.

Kiong, C. C., Arof, M. R., Omar, M. A. H. and Yan K. K. (2005). Pengamalan Kepimpinan Transformasi Di Kalangan Guru Tingkatan Di Tiga Buah Sekolah Menengah Daerah Kulai, Johor. Universiti Teknologi Malaysia: Seminar Pendidikan 2005. Unpublished.

Levesque, K., Laird, J., Hensley, E., Choy, S.P., Cataldi, E.F., and Hudson, L. (2008). Career and Technical Education in the United States: 1990 to 2005 (NCES 2008-035). Washington, DC: National Center for Education Statistics, Institute of Education Sciences, U.S. Department of Education.

Liu, J. and Gentle, A. (2005). Survey of Vocational and Technical Education (VTE): Participation, Triggers, Perceptions and Aspirations. Autralian Goverment : Survey and Workforce Analysis Section, Department of Education, Science and Training. Disember 2005 Research Project. Unpublished.

Lobodzinska, B. (2000). Polish Women's Gender-Segregated Education and Employment. Women's Studies International Forum, 23, 49-71.

Malaysia Ministry of Finance. (2008). Ucapan Bajet Tahun 2008. [Online] Available: http://www.treasury.gov.my (January 3, 2008).

Malaysia Ministry of Higher Education. (2007). Jadual Kemasukan, Enrolmen dan Keluaran di Kolej Komuniti. [Online] Available: http://www.mohe.gov.my/statistik_pdf/4_11_poli.pdf. (December 10, 2007).

Maniam, U. M. and Liong, C. Y. (2007). Persepsi Pelajar Terhadap Atribut Pekerjaan Dan Implikasinya Ke Atas Pendidikan. Butterworh: Sains Malaysiana, 36, 2213-223.

Mesir, B., Mohd Yatim, J., Abd Aziz, A, Jamal, M. H. and Zainal Abideen, M. (2006). Gaya Hidup Pelajar Cemerlang dalam Persekitaran Kampus. [Online] Available: http://eprints.utm.my/475/1/BaharinMesir2006_Gayahiduppelajarcemerlangdalam.pdf (September5, 2008).

Minnis, J.R. (2000). Caught Between Tradition and Modernity: Technical and Vocational Education In Brunei Darussalam. International Journal of Educational Development, 20, 247-259.

Mohd Yusof, Z., Rajuddin, M. R. and Buntat, Y. (2007). Kajian Cabaran Negara Dalam Menyediakan Tenaga Kerja Mahir Tempatan Di Sektor Binaan - Metodologi Penyelidikan. Universiti Teknologi Malaysia: Seminar Pendidikan Teknik dan Vokasional 2007. Unpublished.

Mustapha, K., Mohd Basin, R., and Mohd Ali, R. (2003). Integrasi Akademik dan Vokasional: Rasional dan Cabaran. Jurnal Pendidikan, 28, 77-90.

Oketch, M.O. (2007). To Vocationalise or not to vocationalise? Perspectives on Current Trends and Issues in Technical and Vocational Education and Training (TVET) in Africa. International Journal of Educational Development, 27, 220 - 
234.

Smart, K.L. and Cappel, J.J. (2006). Students' Perceptions of Online Learning: A Comparative Study. Journal of Information Technology Education, 5, 202-219.

Stanwick, J. (2006). Outcomes from Higher-level Vocational Education and Training Qualifications. Adelaide: National Center for Vocational Education Research 2006. Unpublished.

UNESCO-UNEVOC International Center for Technical and Vocational Education and Training (2006). Participation in Formal Technical and Vocational Education and Training Programmes Worldwide: An Initial Statistical Study. [Online] Available: www.unevoc.unesco.org/publications/ (November 5, 2008).

Utusan Malaysia. (2007). Masyarakat Perlu Rebut Peluang Di Kolej Komuniti. [Online] Available: http://www.utusan.com.my/utusan/content.asp? $y=2007 \& d t=0203 \& p u b=U t u s a n \_M a l a y s i a \& s e c=$ Muka_Hadapan\&pg= mh_06.htm. (November 12, 2007).

Velde, C. and Cooper, T. (2000). Student's Perspectives of Workplace Learning and Training in Vocational Education. Education and Training, 42, 83-92.

Wiersma,W. (2000). Research Methods in Education: An Introduction. Boston : Allyn and Bacon.

Wikipedia. (2008). Sijil Pelajaran Malaysia. [Online] Available: http://en.wikipedia.org/wiki/Sijil_Pelajaran_Malaysia (January 7, 2008).

Table 1. Mean Score level

\begin{tabular}{|c|c|}
\hline Mean & Level \\
\hline $1.00-2.33$ & Low \\
\hline $2.34-3.66$ & Moderate \\
\hline $3.67-5.00$ & High \\
\hline
\end{tabular}

Table 2. Perception and Information level for SPM leavers

\begin{tabular}{|l|l|l|}
\hline Mean Score & Mean & \multicolumn{1}{|c|}{ Level } \\
\hline SPM leavers' perception towards community college & 3.66 & Moderate \\
\hline SPM leavers' perception towards courses offered & 3.63 & Moderate \\
\hline SPM leaver's information level towards community college & 3.59 & Moderate \\
\hline SPM leaver's information level towards courses offered & 3.45 & Moderate \\
\hline
\end{tabular}

Table 3. Information sources

\begin{tabular}{|l|c|c|}
\hline Sources & Frequency & Percent \\
\hline School (Counseling and Carrier Unit/teacher) & 75 & 71.4 \\
\hline Parents & 39 & 37.1 \\
\hline Friends & 74 & 70.5 \\
\hline News Paper & 55 & 52.4 \\
\hline Television/ radio & 32 & 30.5 \\
\hline Seminar/ expo/Talks & 44 & 41.9 \\
\hline Officer in school road shows & 35 & 33.3 \\
\hline Pamphlets/articles/brochures & 34 & 32.4 \\
\hline Internet & 36 & 34.3 \\
\hline Other sources : & 10 & 9.5 \\
\hline
\end{tabular}


Table 4. Mean score for courses listed

\begin{tabular}{|c|c|c|}
\hline Courses & Mean & Level \\
\hline Multimedia creative (animation) & 3.31 & Moderate \\
\hline Integrative manufacturing Technology & 2.71 & Moderate \\
\hline Automotive & 3.00 & Moderate \\
\hline Drawing architecture & 2.81 & Moderate \\
\hline Building maintenance & 2.61 & Moderate \\
\hline Electric technology & 2.97 & Moderate \\
\hline Computer system and support & 3.59 & Moderate \\
\hline Hotel Management and catering & 3.69 & High \\
\hline Fashion and Apparel & 3.38 & Moderate \\
\hline Food Processing and quality control & 2.93 & Moderate \\
\hline Construction Technology & 2.79 & Moderate \\
\hline Information Technology & 3.16 & Moderate \\
\hline Accounting & 3.25 & Moderate \\
\hline Multimedia creative (Advertisement) & 3.25 & Moderate \\
\hline Cooling system and air-conditioning & 2.65 & Moderate \\
\hline Tourism and Exploration & 3.67 & High \\
\hline Interior design & 3.17 & Moderate \\
\hline Landscape and nursery management & 3.03 & Moderate \\
\hline Beauty and hair grooming & 3.15 & Moderate \\
\hline Bakery and confectionary & 3.06 & Moderate \\
\hline Ceramic Industry & 2.81 & Moderate \\
\hline Min Score Average & 3.09 & Moderate \\
\hline
\end{tabular}

Table 5. Attributes Concern on Decision Making

\begin{tabular}{|l|c|c|}
\hline Mean Score Average & Mean & Level \\
\hline Confidence in the courses to get job while after complete & 3.70 & High \\
\hline The skills offered in within the courses could entice my interest & 3.74 & High \\
\hline
\end{tabular}


Table 6. Demographic Factors in Comparing Perception

\begin{tabular}{|c|c|c|c|c|c|c|c|}
\hline \multicolumn{2}{|c|}{ Perception and Gender } & $\mathbf{N}$ & Mean & $\mathbf{T}$ & Df & $\begin{array}{l}\text { P Value } \\
\text { Sig. (2-tailed) }\end{array}$ & $\begin{array}{l}\text { Mean } \\
\text { Differs }\end{array}$ \\
\hline \multirow{2}{*}{$\begin{array}{l}\text { Perception } \\
\text { towards courses }\end{array}$} & Female & 56 & 3.6987 & \multirow{2}{*}{2.702} & \multirow{2}{*}{103} & \multirow{2}{*}{.989} & -.0022 \\
\hline & Male & 49 & 3.6964 & & & & -.0022 \\
\hline \multirow{2}{*}{$\begin{array}{l}\text { Perception } \\
\text { towards } \\
\text { community } \\
\text { college }\end{array}$} & Female & 56 & 3.5290 & \multirow[b]{2}{*}{-.014} & \multirow[b]{2}{*}{103} & \multirow[b]{2}{*}{.008} & .2771 \\
\hline & Male & 49 & 3.8061 & & & & .2771 \\
\hline \multicolumn{2}{|c|}{ Perception and SPM result } & $\mathbf{N}$ & Mean & $\mathbf{T}$ & Df & $\begin{array}{l}\text { P Value } \\
\text { Sig. (2-tailed) }\end{array}$ & $\begin{array}{l}\text { Mean } \\
\text { Differs }\end{array}$ \\
\hline \multirow{2}{*}{$\begin{array}{l}\text { Perception } \\
\text { towards courses }\end{array}$} & Pass Exam & 75 & 3.6983 & \multirow[b]{2}{*}{.009} & \multirow[b]{2}{*}{103} & \multirow[b]{2}{*}{.993} & .0025 \\
\hline & $\begin{array}{l}\text { Failure/No } \\
\text { SPM Cert }\end{array}$ & 30 & 3.6958 & & & & .0025 \\
\hline \multirow{2}{*}{$\begin{array}{l}\text { Perception } \\
\text { towards } \\
\text { community } \\
\text { college }\end{array}$} & Pass Exam & 75 & 3.7567 & \multirow[b]{2}{*}{3.068} & \multirow[b]{2}{*}{103} & \multirow[b]{2}{*}{.003} & .3442 \\
\hline & $\begin{array}{l}\text { Failure/No } \\
\text { SPM Cert }\end{array}$ & 30 & 3.4125 & & & & .3442 \\
\hline \multicolumn{2}{|c|}{ Perception and Race } & $\mathbf{N}$ & Mean & $\mathbf{T}$ & Df & $\begin{array}{l}\text { P Value } \\
\text { Sig. (2-tailed) }\end{array}$ & $\begin{array}{l}\text { Mean } \\
\text { Differs }\end{array}$ \\
\hline \multirow{2}{*}{$\begin{array}{l}\text { Perception } \\
\text { towards courses }\end{array}$} & Malay & 56 & 3.8460 & \multirow{2}{*}{1.972} & \multirow{2}{*}{103} & \multirow{2}{*}{.051} & .3179 \\
\hline & Non-Malay & 49 & 3.5281 & & & & .3179 \\
\hline \multirow{2}{*}{$\begin{array}{l}\text { Perception } \\
\text { towards } \\
\text { community } \\
\text { college }\end{array}$} & Malay & 56 & 3.8884 & \multirow[b]{2}{*}{5.102} & \multirow[b]{2}{*}{103} & \multirow[b]{2}{*}{.000} & .4930 \\
\hline & Non-Malay & 49 & 3.3954 & & & & .4930 \\
\hline
\end{tabular}

